\title{
FLIPPING AND STERILIZATION MACHINE FOR POULTRY LITTER
}

\section{T. H. EL-Shabrawy ${ }^{1 *}$}

${ }^{1}$ Assoc. Prof., Ag. Eng. Dept., Ag. Fac., Mansoura U., Egypt.

*E-mail: elshabrawy@mans.edu.eg

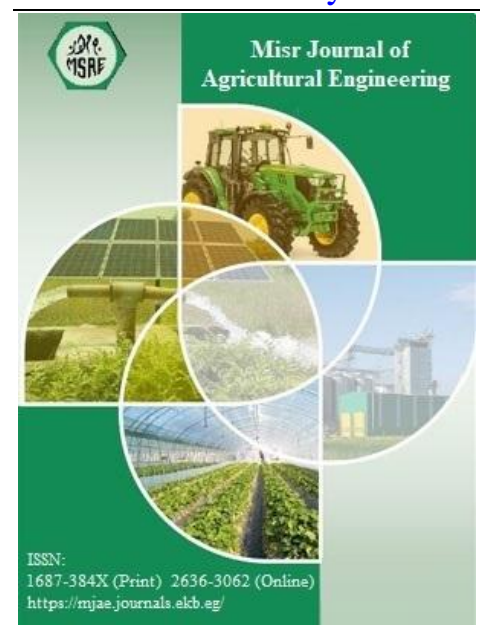

C Misr J. Ag. Eng. (MJAE)

\section{Keywords:}

Poultry litter, laying hens, broiler, litter sterilization, flipping litter

\section{ABSTRACT}

This research aimed to develop and evaluate flipping and sterilization machine "FSM" for poultry litter. The developed was done on the base of rotary blades by adding a steam sterilization unit. The "FSM" attached with sterilization unit was an electrical heating wire. On both side of heater case a two fans were fixed for pumping hot air to poultry litter during flipping process. To avoid a dust and impurities that can be found during operating a flipping unit a filtration system was identified. Evaluation "FSM" performance were done at laying hens farm under fluctuates experiments that included; blades revolutions " $\mathrm{Br}$ " (240, 480 and $960 \mathrm{rpm})$, blades depths "Bd" $(5,8$ and $10 \mathrm{~cm})$ and litter life periods (6, 8 and 10 months) per using and un-using sterilization process (St). The measurements included litter properties as bulk density " $D$ ", clodsize distribution " $C D$ ", mean weight diameter "MWD" and total bacterial counts (BC) CFU/g. All above parameters conducted less than three litter life from cycle period (6, 8 and 10 months). The results showed that using "FSM" reduced bulk density to $0.3 \mathrm{~g} / \mathrm{cm}^{3}$ and the maximum percentage of particle litter size distributions of "CD" recorded $60.3 \%$ with " $M W D$ " of $<2 \mathrm{~cm}$. and reducing microbial count to 105.7 CFU/g under "FSM" operating depth of $5 \mathrm{~cm}$ with rotating shares of $960 \mathrm{rpm}$ at litter life of 10 months from cycle period and using sterilization unit.

\section{INTRODUCTION}

$\mathrm{P}$ oultry wealth especially (broiler chickens \& Laying hens) considered as one of important sources for padding the food gap in developing countries. Poultry litter can be a best friend for bird breeding. It's important due to hold and moldiness functions of poultry fecal and absorbs excess moisture. Leaving the laying hens litter for a long time during period of production cycle (may be up to one year and a half) without flipping (daily) lead to increase the proportion of worms, fungi (E. coli, Clostridium, Salmonella and Pasteurella), moisture content (up $60 \% \mathrm{wb}$ ), $\mathrm{PH}$ of litter ranges between 7.8 and 8.2 and increasing ammonia gases in the litter surrounding hens environment. That led to the infection of the respiratory system of laying hens and negative impact on the rate of production. From here comes the importance of litter flipping process by using a rotary blades periodically in during of laying hens period and replacement constantly litter at the end of breeding cycle. The flipping process was dune using rotary cultivator that the rotary blades are lead to good preparation and flipping soil granules 
(Ismail - 2013). The use of rotary tillers has become wide spread in Egypt due to its suitability for small farms. Also, he added that, the performance of the soil conveyance is lowered when the soil was not sufficiently soft and leveled after tilling. As far as, the quality of the seed-bed per one pass of the rotary tiller is equivalent to several conventional tillage operations. Similarly, the best combination with respect to minimize the required energy at highest of operating rate for a rotary tiller was found at 1.2 speed ratio (rotary per linear speeds) for $12 \mathrm{~cm}$ tillage depth (Kosutic et al. - 1997). Three angles for " $L$ " shape share of rotary cultivator are more effect on the share cutting layers (Ismail - 2018). Rotary tillers prepare the seed-bed fundamentally different than the conventional method of plowing. The soil is pulverized by the cutting and chopping action of a number of blades that receive energy from the tractor or engine (Mandang et al. - 1993). The reverse-rotary tiller cuts and tosses soil slices to backwards which conformed best soil pulverization (Shibusawa - 1993).

Poultry litter is recognized to contain bacteria that have the potential to cause human illness, such as Salmonella and Staphylococcus (Doyle and Erickson - 2008). However, unsuitable use litter with not filliping or replacement can lead to many problems as increase ammonia emission into atmosphere which adversely affects bird performance and health, as well as workers health, leading to loss of profits. Also, the unsuitable use of recycled litter could be increasing coliform levels and coccidian outbreaks in poultry flocks and increasing disease transmission within the farm from flock to flock (Stanley et al. - 2004). From other side, the good poultry litter management practices can reduce ammonia concentrations in poultry houses which volatile by flipping litter volatile by filliping litter (Miles et al. - 2011). Also, the caked litter increases house ammonia levels with negative effects on poultry health (Reece et al. - 1980).

Keeping litter in good condition and avoiding caking are very important because of the high cost of litter materials and because disposal of this litter is becoming more of an environmental issue. In some areas, many growers still practice a traditional total cleanout once a year. These results was estimated by (Payne - 2012) that in broiler litter usually tests approximately 60-6050 (N-P-K) pounds per ton. In the other hand, (Malone - 2006) showed that ensuring healthy and profitable broilers, growers must maintain dry litter. Wet litter greatly increases pathogen load and, therefore, chances of a disease outbreak that may require a total cleanout. However, barring a major disease challenge, some poultry complexes never require a complete cleanout, but rather only need close management of litter depth. (Tabler et al. - 2009) confirmed on the importance of broilers litter that litter production can vary greatly from farm to farm based on house size, harvest weights, management practices and number of flocks per year.

The important thing to remember is always keep litter dry. Poultry litter is a relatively hostile environment for the persistence of pathogens because it is typically dry, heats up readily and generates ammonia gas. Deep stacking or ensiling poultry litter is commonly recommended as a pretreatment to improve its safety and palatability as a feed for ruminants. The wide variation of temperature within the stacks, Salmonella was eliminated in $98.7 \%$ of all inoculated sites (Bush et al. - 2007). Furthermore, Salmonella organisms were reduced by at least to $510 \mathrm{~g}$ in the remaining sites where it was still viable. Ensiling animal waste is also effective in although lactic acid production is thought to be the most important factor, it is not the only mechanism involved. For there more, the problem is set to flipping poultry litter and at same time keeping the atmosphere of laying hens healthy. So, this investigation was done to develop and evaluate 
the flipping and sterilization machine "FSM" for poultry litter. To recognize this objective a try was done to:

1- Develop a rotary blades to be operating in laying hen's farm and flipping the poultry litter.

2- Fabricate the sterilization unit and conduct it with the rotary flipping unit.

3- Adding a filtration system to avoid a dust and impurities that can be formed during operating a flipping unit.

\section{MATERIALS AND METHODS}

The experiments were done in laying hen's farm Khearia village-Dakahlia governorate- Egypt at 2018 to 2019 period. The flipping sterilization machine "FSM" was manufactured in locally workshop at Mansoura city. Its main dimensions are $1360 \times 1000 \times 850 \mathrm{~mm}$ length, width and height respectively as shown in Fig. (1A). It manually driven by pulling with labor hand and it is loaded on 4 wheels. The "FSM" connected with an electric motor of $220 \mathrm{~V}, 0.5 \mathrm{~kW}$ and 480 rpm attached with pulley and belt to appropriate movable motor rotation to rotor shaft with $\mathrm{L}$ shape blades and also supply electricity power to sterilization and filtration units. On the base of this study, three functions were illustrated mainly were flipping, sterilization and filtration units Figs. (1-A and 1-B).

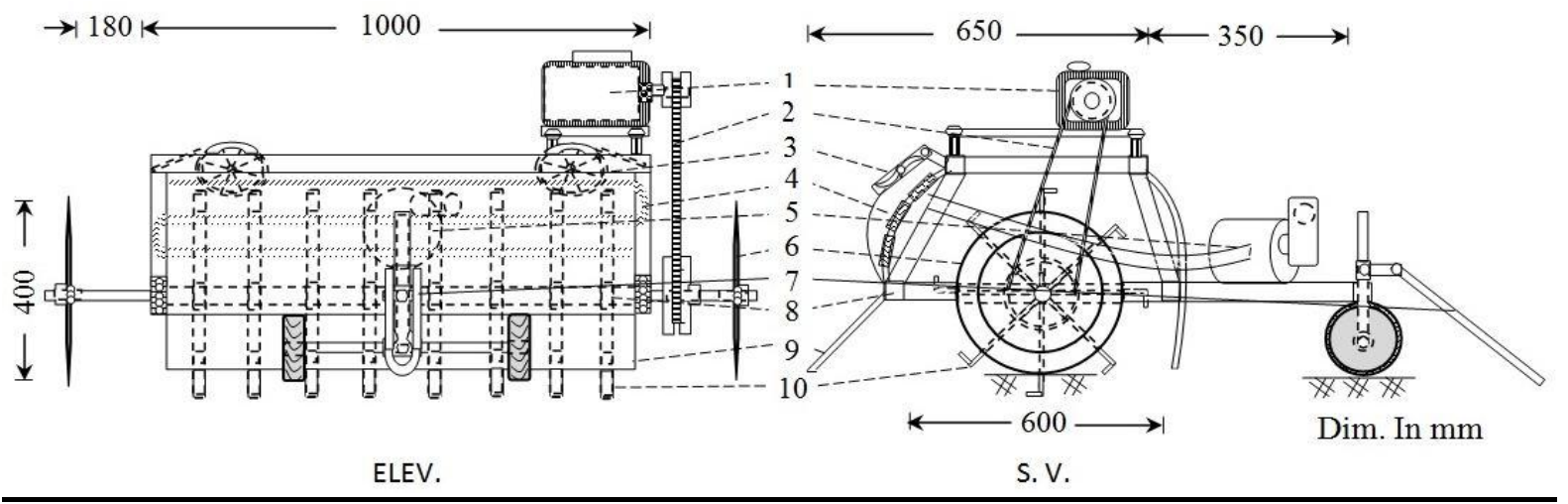

1- Electric motor.

6- Disk wheel.

2- Transmission system (belt and pulleys). 7- Pull arm

3- Fan.

8- Chassis

4- Electric heater.

9- Cover of rotary blades

5- Filtration unit.

10- L shape blades

Fig. (1-A): A schematic diagram of (FSM) machine with main dimensions

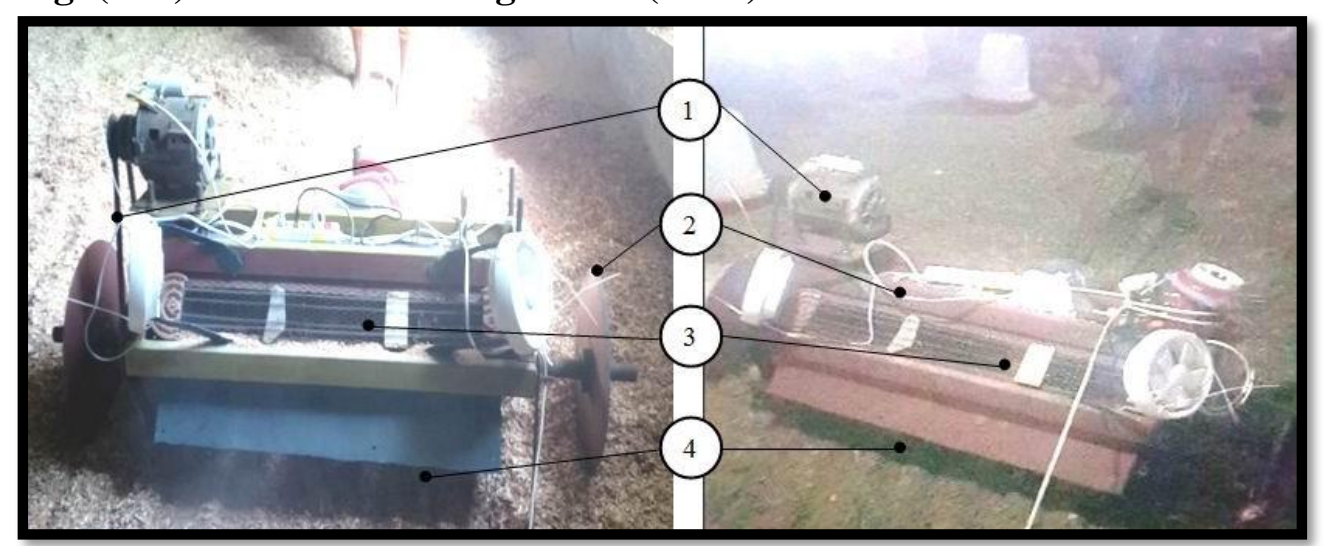

1- Electric motor with pulleys and belt. 3- Sterilization unit.

2- Main frame with carriage wheels. 4- Rotary blades.

Fig. (1-B): The main parts of (FSM) machine 


\section{Flipping unit}

Main frame height of flipping unit is $600 \mathrm{~mm}$ covered with steel sheet of $2.5 \mathrm{~mm}$, attached with 2 carriage wheels and two pull arms with 2 depth control wheels are connected at frame. The flipping unit includes eight flanges fixed on rotor axis of $50 \mathrm{~mm}$ diameters. For each flange four tines " $L$ " shape shares were adding on rotary shaft to overturn poultry litter.The main axis of rotary L shape blades attached with three pulleys to obtain different blades revolutions as shown in Fig.(2) The electrical power is supply to rotor flipping shaft under three motion ratios to utilize the certain rotation.

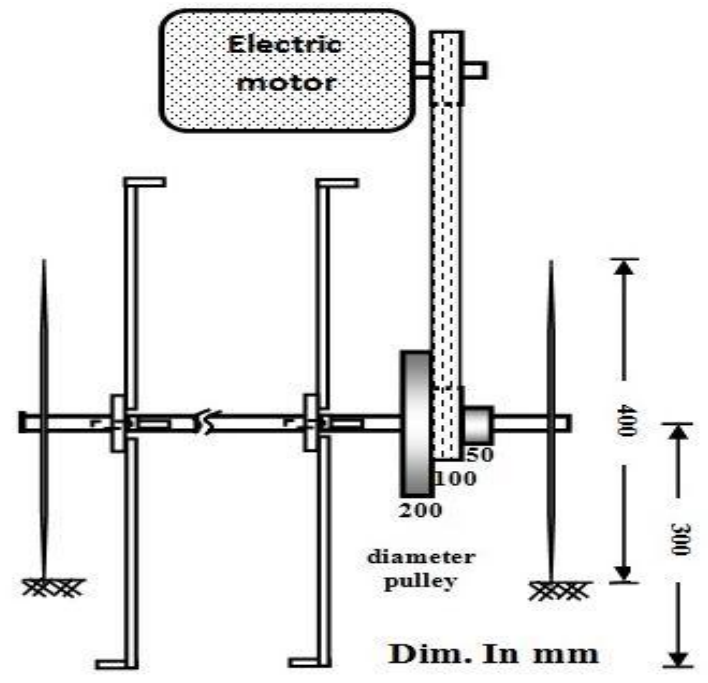

Figure (2): main parts of flipping unit.

\section{Sterilization unit}

It is an electrical heating wire (750 Watt). The two free end of this wire located inside the top rotor level of cultivator by two insulating bearing. On both side of heater case a two fan was fixed for pumping a hot air to poultry litter during flipping. To avoid a dust and impurities that can be found during operating a flipping unit a filtration system is identified as showed in Fig. (3A).

\section{Filtration unit}

It is used to purify the air from drying dust and impurities surround machine rotary blades during flipping process, it consists of box containing sponge that absorbs water in the outside air as well as the reservation of any other impurities by air suction inside the filter using air suction pump as shown in Fig. (3B).

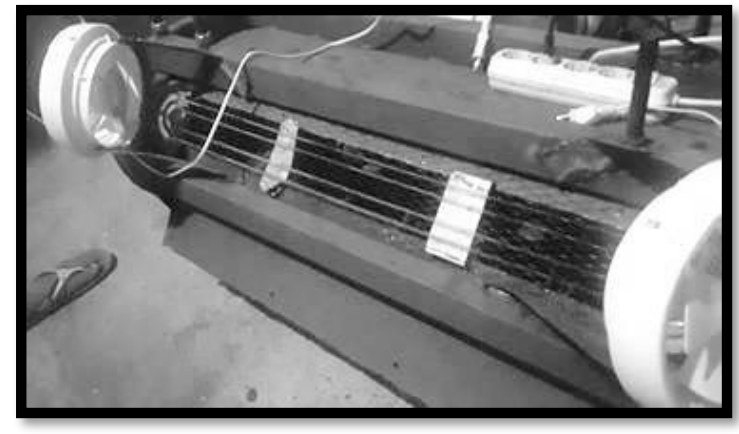

Figure (3A): Sterilization system.

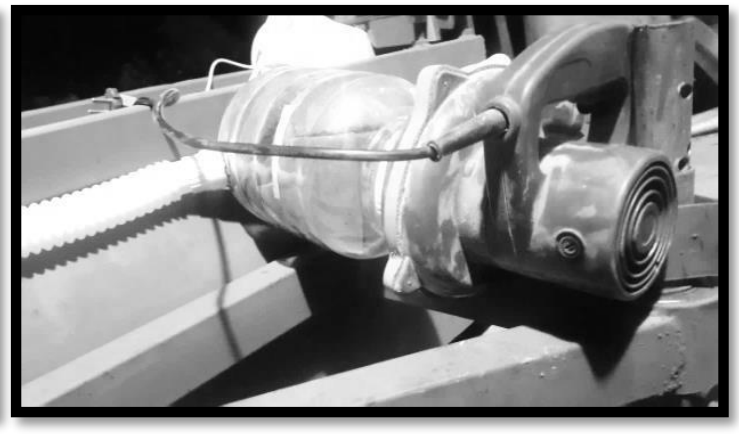

Figure (3B): Filtration system. 
Flipping and sterilization machine operation

At moment of dragging the "FSM" on the litter surface and contact the electrical motor, the rotor axis of blades rotating at specified controlling depth then the " $L$ " shares penetrate, cut and lift out the litter layer. At this moment, the sterilization system pushing and pumping a hot air in space between shares and litter granules Fig. (4). The impurities, duct and the up-rising gases are forced to a suction fan throughfilter which retains pushing to keep litter in good condition.

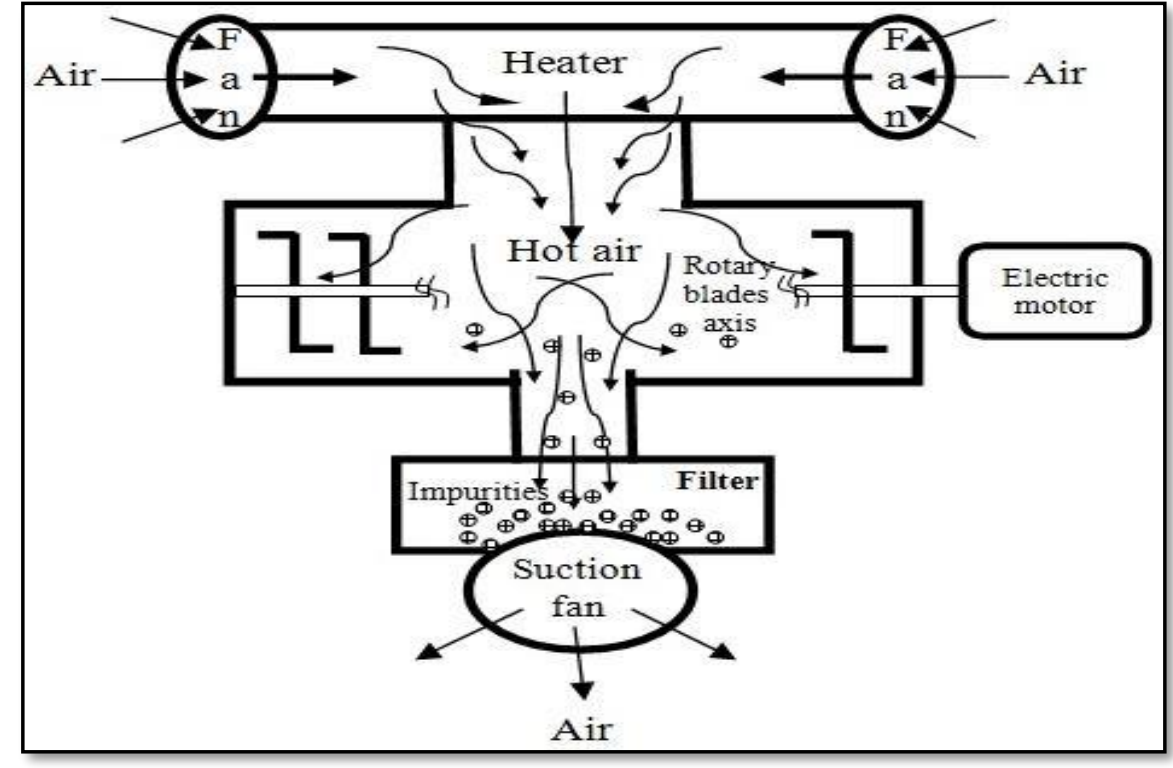

Figure (4): A sketch diagram of sterilization and filtration cycles

\section{The experimental variables}

Four experimental variables under study were conducted to assess the performance of "FSM" as follow:

1) Three blades revolutions "Br" (240, 480 and $960 \mathrm{rpm})$.

2) Three levels of blades operating depths "Bd" $(5,8$ and $10 \mathrm{~cm})$.

3) Sterilization process, using ( $\left.\mathbf{S t}_{\mathbf{1}}\right)$ and un-using $\left(\mathbf{S t}_{\mathbf{2}}\right)$.

4) Three different litter time periods Mt (6,8 and 10 months) from litter breeding life.

The worker operations "LD" were dun and compared with the machine operating under above parameters. (For each test five randomizes samples of $5.0 \mathrm{~kg}$ per one were taken from five different places of poultry litter farm to evaluate "FSM" performances).

\section{The outlet evaluations}

1) Litter bulk density (D) $\mathbf{g} / \mathbf{c m}^{3}$ : The bulk density of the farm litter estimated before and after flipping operation of "FSM". The 10 samples of litter were taken randomly by cone its volume $200 \mathrm{~cm}^{3}$ then weight the sample under average of experimental blades depths $(5,8$ and $10 \mathrm{~cm})$ per different blades rotation. The samples mass was estimated by digital balance with accuracy one gram. All litter bulk density were evaluated under average litter moisture content of 25 $30 \%$ for 5,8 and $10 \mathrm{~cm}$ of operating blade depths.

2) Litter Clod size distributions (CD) \%: It was appreciated using crumb structure measuring device. It consisted of three sieves having different mesh sizes. The diameter of each sieve is $20 \mathrm{~cm}$ and the mesh sizes are 80,50 and $20 \mathrm{~mm}$. Litter samples were randomly taken from five different places of poultry litter farm and there were air dried. The two $\mathrm{kg}$ of air dried sample 
was putted into a semi-circular fashion for one minute. After sieving all samples under each treatment, they massed and the percentages of each litter granules category were calculated.

3) Mean weight diameter of litter granules (MWD) mm: After sieving all samples under each treatment individual were massed and calculated the mean weight diameters of litter granules (MWD) from following formula (Ismail et al. - 2011):

$$
M W D=\frac{1}{W}(10 A+35 B+65 C+90 D)
$$

Where: A \& B \&... D = weight of separated litter sample by the set, $\mathrm{kg}$.

$$
\mathrm{W}=\mathrm{A}+\mathrm{B}+\ldots \mathrm{D}, \mathrm{kg} \text {. }
$$

4) Total bacterial counts (BC) CFU/g: About $90 \mathrm{ml}$ of sodium phosphate solution $0.1 \%$ concentration prepared then 10 grams of litter samples were added to it and homogenized for $30 \mathrm{~min}$, mitigation to make serials from 101 to 107 were made and aliquots of the resulting solutions then solution plated on count agar medium plate. Agar plates incubated at $30^{\circ} \mathrm{C}$ for 48 h., and bacterial colony forming units (CFU) were counted according to (Vieira and Nahas 2005).

5) FSM operating cost (OC): The fixed and operating costs estimated according to $\underline{\text { (Extension }}$ and Outreach - 2015) which calculate the total cost of the presented farm area under study (9 $\times 12 \mathrm{~m}$ ) using the "FSM" compared to the traditional litter flipping method (manual). The main items and values of fixed and operating costs are tabulated in Table (1).

Table (1): The main items and values of fixed and operating costs at flipping process only.

\begin{tabular}{|l|c|c|}
\hline \multicolumn{1}{|c|}{ Items } & Manual & Mechanical \\
\hline $\begin{array}{l}\text { Labor number } \\
\text { Flipping process cost LE/h of flipping } \\
\text { process for 1 labor }\end{array}$ & 2.5 & 1 \\
\hline Operating time, min / farm area (9×12 m) & 50 to 60 & 10 to 15 \\
\hline Working days & 180 & 60 \\
\hline Fixed cost LE & 10 & 22.18 \\
\hline Operating cost LE & 2.5 & 18.37 \\
\hline
\end{tabular}

3. RESULTS AND DISCUSSION

\section{Litter bulk density (D) $\mathbf{g} / \mathrm{cm}^{3}$}

The results illustrated in Fig. (5) showed that the less values of litter bulk density obtained using (FSM) for different experimental factors under study compared to manual litter flipping where, the density values ranged from 0.63 to $0.73 \mathrm{~g} / \mathrm{cm}^{3}$. While the use of the machine in the flipping process led to low density values and the lowest value of litter density was $0.3 \mathrm{gm} / \mathrm{cm}^{3}$ obtained at least depth of blades $\left(\mathrm{Bd}_{1}=5 \mathrm{~cm}\right)$ and heist blades revolution $\left(\mathrm{Br}_{3}=960 \mathrm{rpm}\right)$ with sterilization process at 6 months litter life period, while the heist density value obtained with used (FSM) machine was $0.56 \mathrm{gm} / \mathrm{cm}^{3}$ at heist depth of blades $\left(\mathrm{Bd}_{3}=10 \mathrm{~cm}\right)$ and revolution $\left(\mathrm{Br}_{1}=240 \mathrm{rpm}\right)$ without sterilization process at 10 months litter life period. From the previous it can see the positive effect of the disassembly mechanical flipping process of litter. These results may be due to the highest blade revolutions the litter repeat lifted in the same place move times and at the shallow depth leads the little amount of lifting litter. 
Without sterilization

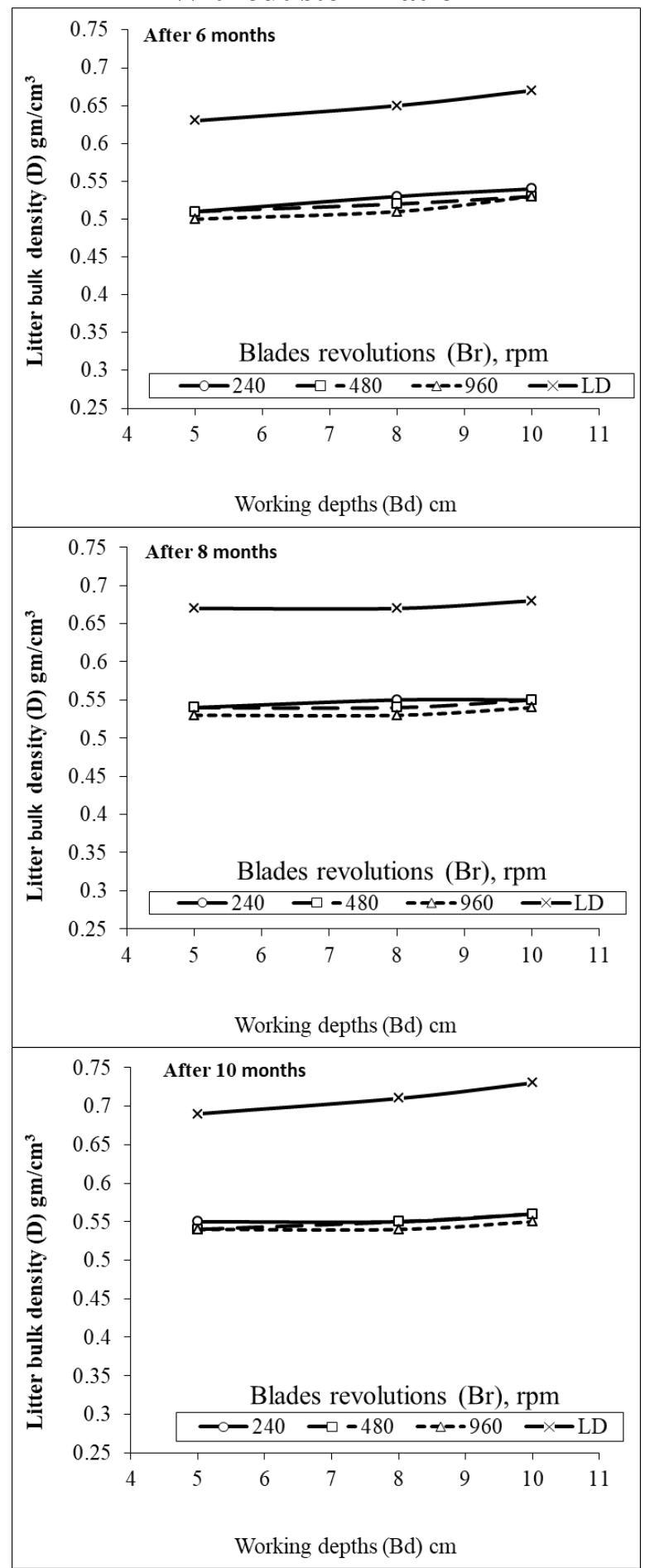

\section{With sterilization}
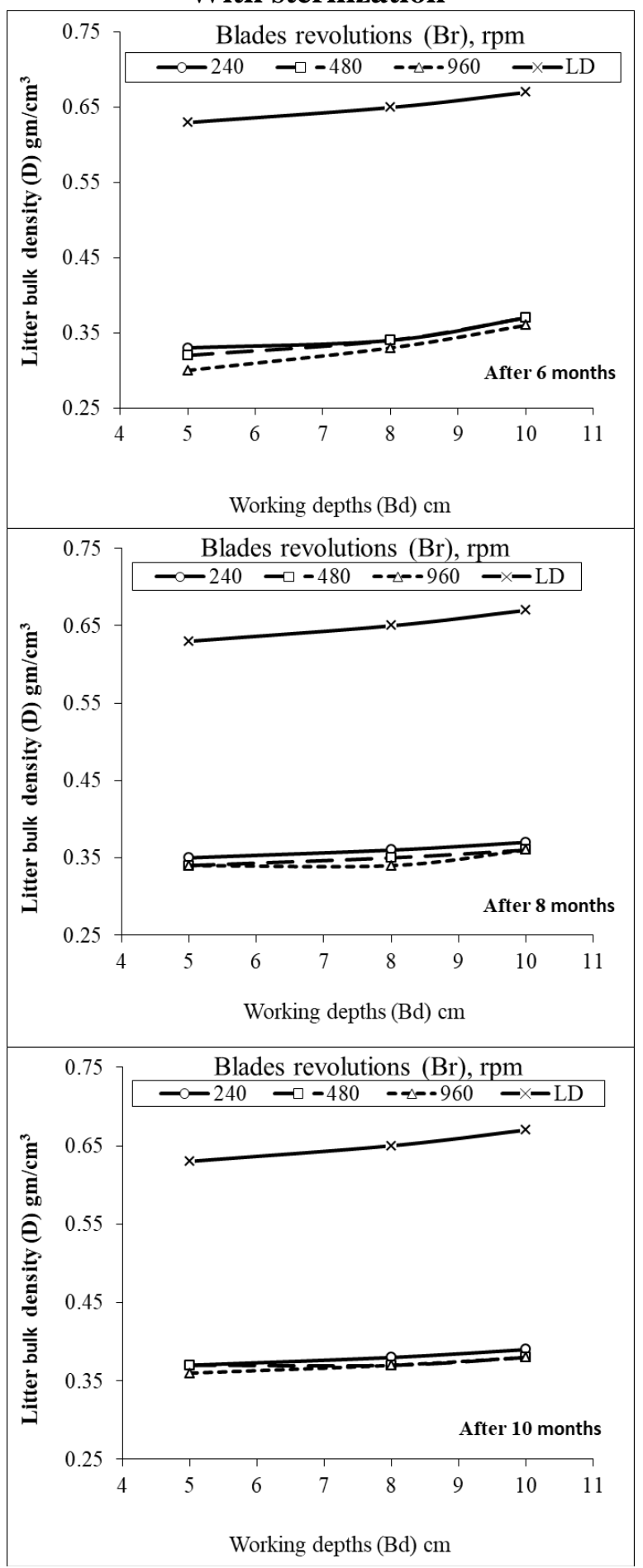

Figure (5): Effect of working depth (Bd) on litter density (D) at different blades revolutions (Br) and different litter life period (Mt) under study, with or without sterilization process (St).

\section{Litter clod size distributions (CD) \%}

Figure (6) show the variation in each range of clod size due to the different reaction of crash of rotary blades on the litter constructer. The obtained data indicated that, there is a difference between thepercentages of amount of clod diameter (\%) for different (FSM) machine factors under study comparing with labor litter flipping process (LD). Using machine blades in high rotary revolutions had a good effect on litter mechanical properties. The lowest value of clod 
size distribution $(<2 \mathrm{~cm}=42.1 \%)$ obtained with highest working depth $\left(\mathrm{Bd}_{3}=10 \mathrm{~cm}\right)$ at the lowest blades rotary revolution $\left(\mathrm{Br}_{1}=240 \mathrm{rpm}\right)$ at 6 months litter life period. Also Fig. (6) show that by increasing blades rotary revolution from $\left(\mathrm{Br}_{1}=240\right.$ to $\left.\mathrm{Br}_{3}=960 \mathrm{rpm}\right)$ and litter life period to 10 months gave high clod diameter $\%(<2 \mathrm{~cm}=60.3 \%)$ at lowest working depth $\left(\mathrm{Bd}_{1}=5\right.$ $\mathrm{cm})$, that is may be due to increasing of blades rotary revolution caused cracking of litter structure at shallow working depths and increasing litter life period from (6 to 10 months) lead the litter to be more disassembled.

- 6 months litter breeding life:
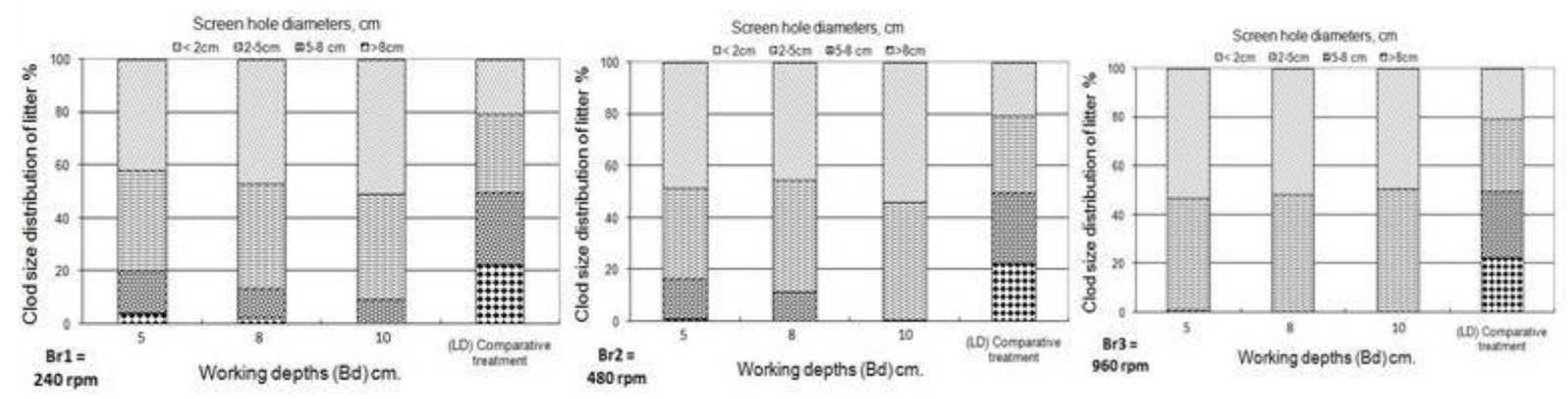

- 8 months litter breeding life:
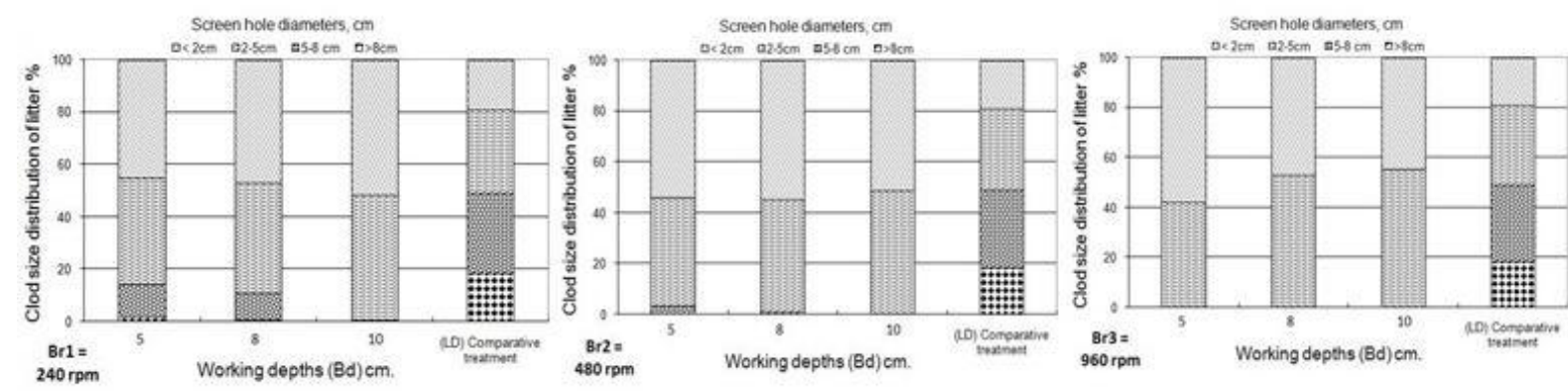

- 10 months litter breeding life:
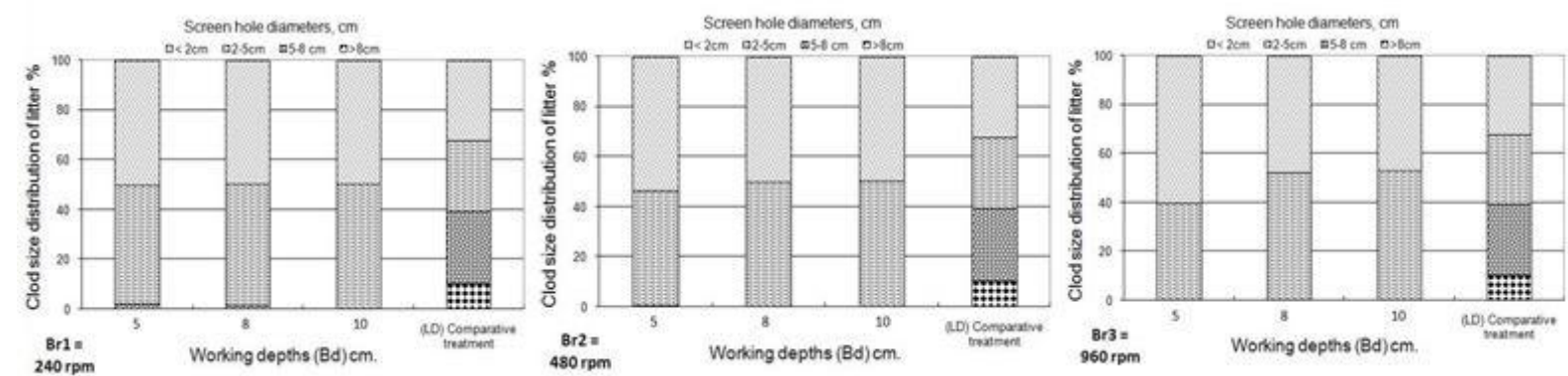

Figure (6): Clod size distributions \% for different working depths (Bd) and blades revolutions $(\mathrm{Br})$ at different litter life periods $(\mathrm{Mt})$

\section{Mean weight clod diameter (MWD):}

Figure (7) shows the maximum reduction in percentage of (MWD) by using (FSM) it was 47.41, 53.51 and $55.76 \%$ at 5,8 and $10 \mathrm{~cm}$ working depths and 240, 480 and $960 \mathrm{rpm}$ blades revolutions respectively for litter breeding life after of 6 month. Meanwhile, the corresponding values at breeding life of 8 months were 52.49, 52.80 and 55.22\% respectively, at the above working depths and blades revolutions. While, after 10 months the reduction in percentage of (MWD) were 52.27, 53.26 and 53.56\% respectively at 5, 8 and $10 \mathrm{~cm}$ working depths and 240, 480 and $960 \mathrm{rpm}$ blades revolutions. These results may be due to increasing the period life of 
the litter inside the farm and with the daily flipping of the litter, it leads to the dismantling of its particles, at the lower litter layers with the highest level of moisture content at the lower litter layers compare with top layer of the litter.
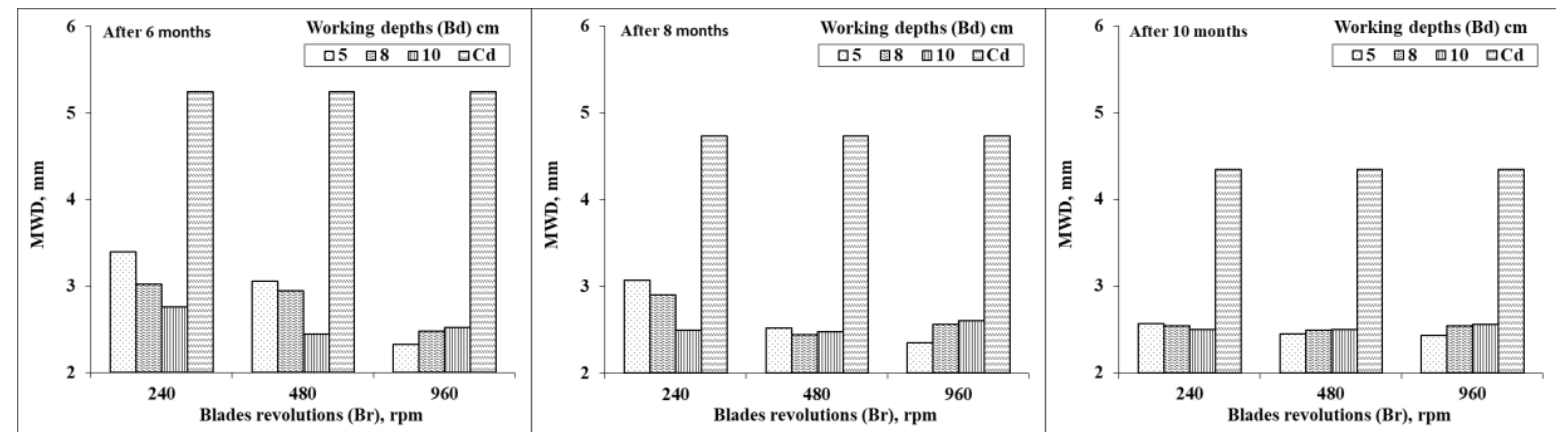

Figure (7): MWD for different working depths (Bd) and blades revolutions (Br)at different litter time periods (Mt).

\section{Total bacterial counts (BC)CFU/g}

Figure (8) showed that using the "FSM" machine with sterilization system had positive effect on reducing total bacterial counts\% with all another different factors under study comparing with disuse sterilization system during litter flipping process. Less value of total bacterial counts (105.7 CFU/g) obtained with low blades depth $\left(\mathrm{Bd}_{1}=5 \mathrm{~cm}\right)$ and blades rotary revolution $\left(\mathrm{Br}_{3}=\right.$ $960 \mathrm{rpm}$ ) at 6 months litter life period with using sterilization system during litter flipping process.
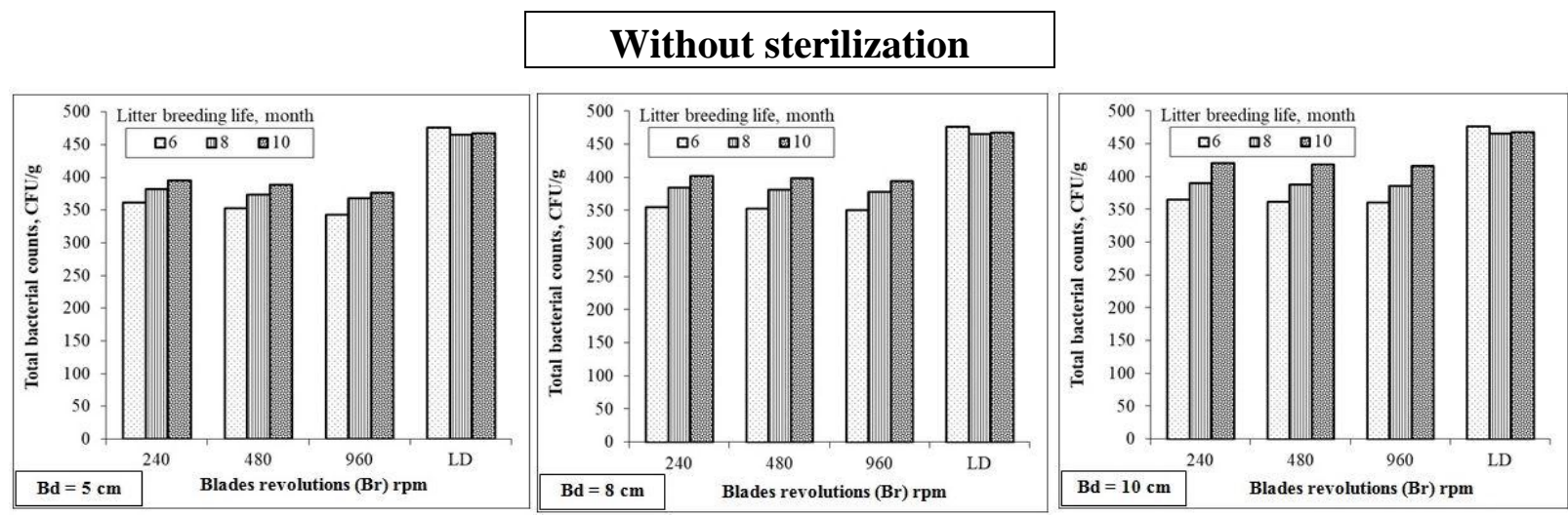

\section{With sterilization}
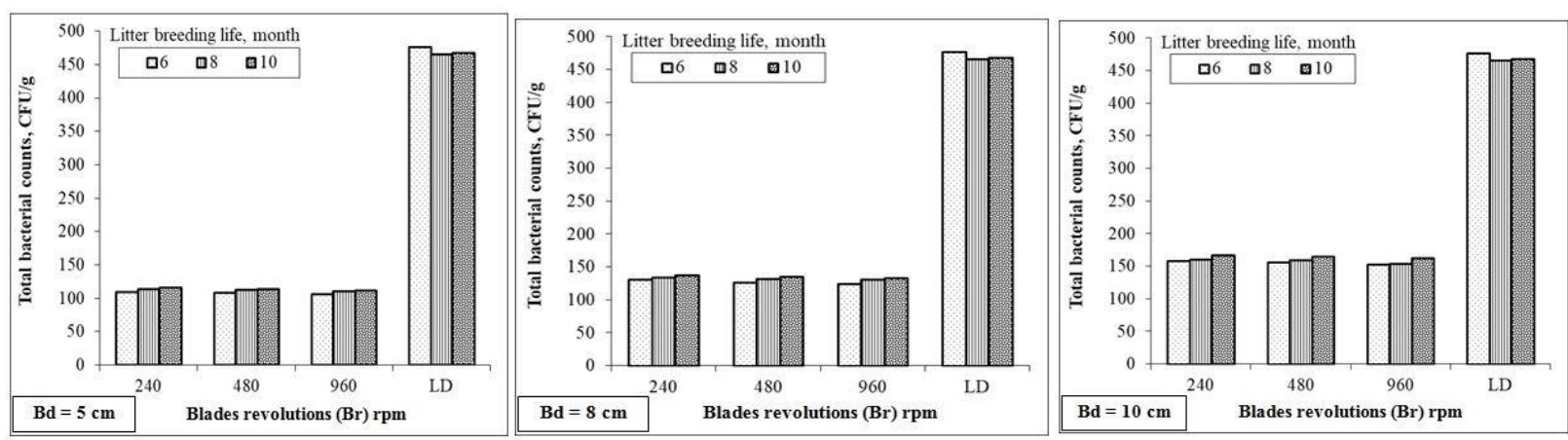

Figure (8) : Effect of rotary blades depths on total bacterial counts CFU/g at different blades revolutions (Br) and different litter life period (Mt) under study. 


\section{CONCLUSION}

The (FSM) machine had a positive effect on poultry litter flipping and sterilization process with different experimental factors. From the results of the experiment, less values oflitter density $0.3 \mathrm{gm} / \mathrm{cm}^{3}$, best range of clod size distribution $<2 \mathrm{~cm}$ diameter $=60.3 \%$ at 10 months of the litter breeding life obtained by using "FSM" machine withworking depth of $\mathrm{Bd}=5 \mathrm{~cm}$. and blades revolutions $\mathrm{Br}=960 \mathrm{rpm}$, on the other side we can see clearly the good effect using sterilization system during litter flipping process led to reduce total bacterial counts to level 105.7 CFU/g.

\section{REFERENCES}

AboEl-Ees N. (1985). Mechanics of operation of rotary tillers. Misr J. Ag. Eng., 2 (4):107-120.

Bush, D. J.; M. H. Poore; G. M. Rogers and C. Altier (2007). Effect of stacking method on Salmonella elimination from recycled poultry bedding. Bioresour. Technol. 98:571-578.

Doyle, M. P. and M. C. Erickson (2008). The problems with fresh produce: An overview. Summer meeting 2007-J. Appl. Microbiol. 105:317-330.

Extension and Outreach (2015). Estimating farm machinery costs. Iowa State University. Ag Decision Maker, PM 701.

Ismail Z. E. (2018). Basics of power and machinery in agricultural engineering. Part one, Specifications and Operation, Mansoura University.

Ismail, N. K.; O.T. Bahnas and S.A. Badr (2011). Complete system to produce rabbit pellets using plant residues. The $4^{\text {th }}$ Sci. Conf. of Animal wealth Researchers In the Middle and North Africa 3-5- October. Middle East and North Africa Journal of animal science and CAB International Association www.cabi.org.

Ismail, Z.E. and N.K. Ismail (2013). Soil layer deformation model during wide raised beds construction. Australian Journal of Basic and Applied Sciences, 7(10): 20-30. ISSN 19918178 .

Kosutic, S.; D. Filipovic and Z. Gospodaric (1997) Agro-technical and energetic characteristics of a rotary cultivator with spike tines in seed-bed preparation. Agric. Eng. J. 6, 137 - 144.

Malone, B. (2006)Managing built-up litter. Proc. Mid- west Poultry Federation Conf. March 21-23. St. Paul, MN.

Mandang, T. F.; N. Hayashi, S. Watanabe, and S. Tojo, (1993). Studies on the overturning properties of soil by rotary blade using CT image analyzer. ASAE Paper No. 93 - 3035, American Society of Agricultural Engineers, St. Joseph, MI.

Miles, D. M.; D. E. Rowe, and T. C. Cathcart (2011). High litter moisture content suppresses litter ammonia volatilization. Poultry Science 90 : 1397-1405.

Payne, J. (2012). Litter management strategies impact nutrient content. Poultry Practices.Vol.2(1). 1-3. Okla. Coop. Ext. Ser.

Reece, F. N.; B. D. Lott and J. W. Deaton (1980). Ammonia in the atmosphere during brooding affects performance of broiler chickens. Poult Sci. 59:486-488. 
Shibusawa, S. (1993). Reverse rotational rotary tiller for reduced power requirement in deep tillage. J. Terramech. 30, $205-217$.

Stanley, V. G.; C. Gray; M. Daley; W. F. Krueger and A. E. Sefton (2004). Analternative to anti biotic based drugs in feed for enhanc ing performance of broilers grown on Eimeriaspp. Infected litter. Poult. Sci.,83:39-44.

Tabler, G. T.; Y. Liang and K. W. Van-Devender (2009). Poultry litter production and associated challenges. Avian Advice. Vol. 11 (2):8-10.

Vieira F.C.S. and E. Nahas (2005).Comparison of microbial numbers in soils by using various culture media and temperatures. Microbiological Research; Sciencedirect journal160: 197-202. 


\section{آلة تقليب و تعقيم فرشة الطيور الداجنة}

طارق حسني الشبراوي' - مارن

' أستاذ الهندسة الزر اعية المساعد ـ كلية الزر اعة - جامعة المنصورة - مصر.

الملخص العربي

تقليب الفرشة خلال دورة تربية الدواجن و إحلالها فى نهاية الدورة من الأمور الهامة للتخلص من الرطوبة الزائدة والتهوية لتجنب نمو البكتريا الفطريات و وعدم إنتشار

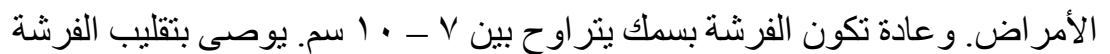

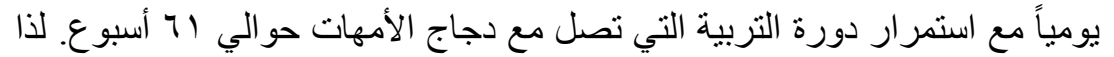

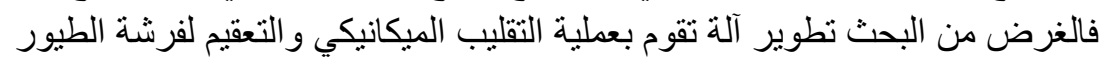
الداجنة. وتتكون الآلة من وحدة تقليب مزودة بأسلحة دو ارة ملحق بها موتور كهربائي 0, • كيلو و ات مزودة بنظام تنقية (فلترة) و تعقيم (هو اء ساخن) للفرشة أثناء عملية

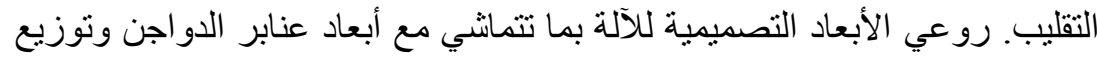
السقايات و العلافات فى حدود ب م بين كل و احدة و أخرى. تم تصنيع الآلة و إجر اء اء

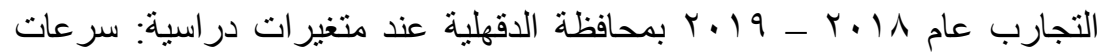

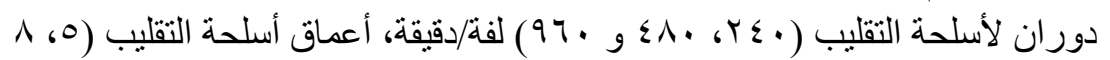

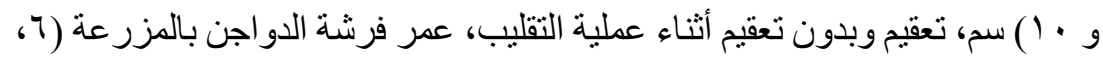
1 و • ( شهور )، و وتم قياس الآتي: كثافة فرشة الدو اجن جم/سمّاء، حجم وترتيب جزيئات

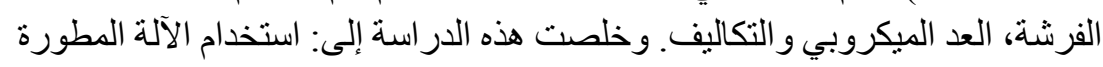

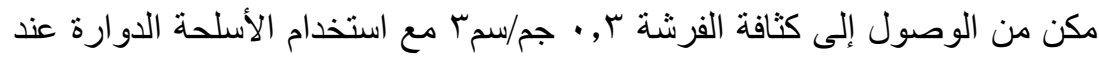

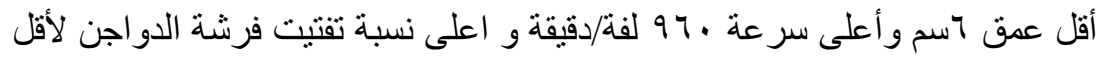

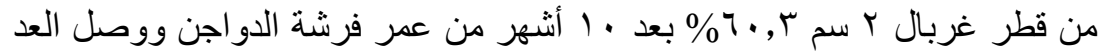

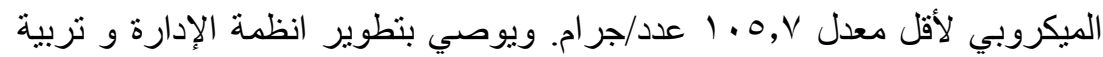

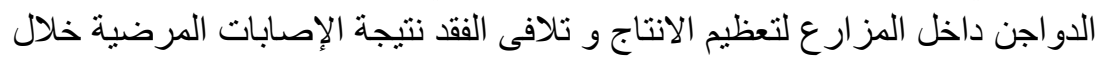

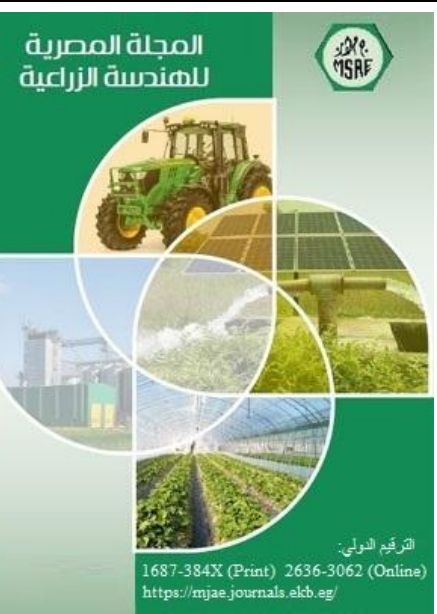

C) (المجلة المصرية للهندسة الزراعية

الكلمات المفتاحية:

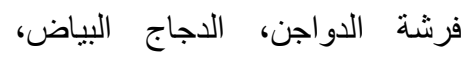
الاجاج اللاحم، تعقيم الفرشة، تقليب الفرشة 